\title{
The Trajectories, Trends, and Opportunities for Assessing Urban Ecosystem Services: A Systematic Review of Geospatial Methods
}

\author{
Muhammad Zaman-ul-Haq ${ }^{1}$, Zafeer Saqib ${ }^{1}$, Ambrina Kanwal ${ }^{2}$, Salman Naseer ${ }^{3}$, ${ }^{2}$, Muhammad Shafiq ${ }^{4, *(1)}$, \\ Nadia Akhtar ${ }^{5}$, Syed Atif Bokhari ${ }^{6}$, Azeem Irshad 7 (1) and Habib Hamam $8,9,10$ (1)
}

1 GIS and Eco-Informatics Laboratory, Department of Environmental Science, Male Campus, International Islamic University, Islamabad 44000, Pakistan; zaman@iiu.edu.pk (M.Z.-u.-H.); zafeer@iiu.edu.pk (Z.S.)

2 Department of Computer Sciences, Bahria University, Islamabad 44000, Pakistan; ambrina_kanwal@yahoo.com

3 Department of Information Technology, Gujranwala Campus, University of the Punjab, Gujranwala 52250, Pakistan; salman@pugc.edu.pk

4 Department of Information and Communication Engineering, Yeungnam University, Gyeongsan 38541, Korea

5 Department of Environmental Science, Female Campus, International Islamic University, Islamabad 44000, Pakistan; nadia@iiu.edu.pk

6 Department of Geography, Government College, Asghar Mall, Rawalpindi 46000, Pakistan; syedatifbokhari@gmail.com

7 Department of Computer Science and Software Engineering, International Islamic University, Islamabad 44000, Pakistan; irshadazeem2@gmail.com

8 Faculty of Engineering, Université de Moncton, Moncton, NB E1A3E9, Canada; habib.hamam@umoncton.ca

9 Spectrum of Knowledge Production \& Skills Development, Sfax 3027, Tunisia

10 School of Electrical Engineering, Department of Electrical and Electronic Engineering Science, University of Johannesburg, Johannesburg 2006, South Africa

check for
updates

Citation: Zaman-ul-Haq, M.; Saqib, Z.; Kanwal, A.; Naseer, S.; Shafiq, M.; Akhtar, N.; Bokhari, S.A.; Irshad, A.; Hamam, H. The Trajectories, Trends, and Opportunities for Assessing Urban Ecosystem Services: A Systematic Review of Geospatial Methods. Sustainability 2022, 14, 1471. https:// doi.org/10.3390/su14031471

Academic Editors: Agnieszka Dawidowicz and Agnieszka Trystuła

Received: 21 December 2021

Accepted: 24 January 2022

Published: 27 January 2022

Publisher's Note: MDPI stays neutral with regard to jurisdictional claims in published maps and institutional affiliations.

Copyright: () 2022 by the authors Licensee MDPI, Basel, Switzerland. This article is an open access article distributed under the terms and conditions of the Creative Commons Attribution (CC BY) license (https:// creativecommons.org/licenses/by/ $4.0 /)$.
* Correspondence: shafiq@ynu.ac.kr; Tel.: +82-10-7145-4060

\begin{abstract}
Urban ecosystem services (UES) are indispensable for life. Stakeholders are improvising strategies for a more sustainable provisioning of UES. For this purpose and for identifying orientations towards geospatial data in UES studies, the "bibliometric analysis" technique was deployed. The inclinations facilitate assessments pertaining to spatio-temporal oscillations in the supply-demand equilibrium. The propensities are gaining recognition due to time and cost effectiveness. Besides this, Remote Sensing (RS) in conjunction with Geographic Information System (GIS), enables the conduct of synoptic and robust periodic evaluations. The study analyzes inclinations towards RS in contemporary research (2010-2020) focusing, particularly, on urban ecosystem services. It specifically focuses on methodological frameworks and major sources of remotely sensed data. Therefore, a total of 261 records of research articles were identified and retrieved. Subsequently, 79 articles were selected for further processing and content analysis. It transpired that approximately $30 \%$ of the selected publications deployed remotely sensed data for assessment purposes. The majority (96\%) of such studies were conducted in economically developed and industrialized countries. However, the researchers from both developed and developing countries prefer open software and free data sources. Besides this, they prefer satellite-based optical sensors over image sensors such as TIR, SAR, or light sensors for acquiring data. The findings formulate that Land Use Land Cover (LULC)-based methodologies and inclinations for assessing regulating services are more frequently pursued. The findings revealed that enhanced research collaborations, access to data, and assessment gadgets are obligatory for capacity building in developing regions. Knowledge sharing and cost-effective access to RS and GIS based platforms are incumbent for ensuring urban environmental sustainability in developing economies.
\end{abstract}

Keywords: urban ecosystem services; urbanization; environmental resilience; remote sensing 


\section{Introduction}

Ecosystem Services (ES) are the sum total of the functions, processes, and benefits that stem from ecological resources [1-3]. The reimbursements of natural capital (bluegreen surfaces) are indispensable for the biosphere [4] and are classified into four distinct groups and various categories [5]. The provisioning of ES is symptomatically determined by the nature of biophysical infrastructure, its associated processes, and accompanying changes. Thus, they have spatio-temporal connotations, implications, and dimensions which have persistent bearings on the ecosystems and the services rendered by them [6]. Therefore, human beings are endeavoring to decipher the linkages between society and their environment from various perspectives [7]. The publication of Millennium Ecosystem Assessment (MEA) in 2005 proved to be a catalyst for launching an invigorative quest for monitoring the resilience of ecological resources [4].

Urban Ecosystem Services (UES) is an observational term used for assessing, evaluating, and portraying ecological infrastructure and its products in the urban areas. The information is collected for detecting spatio-temporal oscillations in the supply-demand budget of UES [8]. These estimations/information assist to determine whether the observed changes are the products of human interventions or nature-triggered modifications.

The reported demographic pressures [9], such as uncontrolled urbanization [10], access to technological gadgetry [11], and socio-economic changes [12] are embossing their indelible imprints on urban environment. Contrary to that, the required focus and actions are, still, far from the desired benchmarks in developing regions [13-16]. It entails informed assessments, coordinated efforts, and tangible measures for protecting urban ecological resources [17]. However, resource constraints thwart such proclivities which are vitally required for a resilient urban social life.

The evaluation of UES is carried out by deploying monetary and non-monetary based mechanisms. Bokhari et al. [8] opined that monetary-based tools and techniques are more suitable measures for documented economies. Whereas, non-monetary parameters seem to be a pragmatic option for transforming/developing economies, which are struggling with issues pertaining to undocumented financial transactions $[4,13]$. Recent advances in the domain of Remote Sensing (RS) offer time and cost-effective possibilities for assessing ES and their services $[15,18]$. The embedded features of Geographic Information System (GIS) and RS enable the conduct of synoptic, spatially connected, and periodic measurements in a synchronized manner. The information is utilized for interpreting man-environment interactions in a given urban setting [19].

Albeit, RS-based assessments are gaining recognition as a reliable option for modeling, mapping, and assessing ecosystems and their products [20-22]. Remotely sensed data is deployed for analyzing urban Land Use Land Cover (LULC) transformations [23-25], assessing urban heat island effect [26,27], and studying urban green species [28,29]. The data source is useful for detecting transitions in urban vegetative cover [30], water quality [31], and biomass estimation with the help of ALOS-2, PALSAR-2, and Sentinel-2A images [32]. The initiatives are obligatory for ensuring sustainable cities and societies as envisaged in (SDG 11) [33,34].

The scenario entails for assessing the potentials of RS for ensuring urban ecological integrity. Therefore, the present study is designed in order to demonstrate the role and potentialities of remote sensing for assessing UES. It analyzes inclinations towards RS in contemporary research (2010-2020) focusing on urban ecosystem services. For this purpose, a systematic review of literature was carried out. Hence, the present study focuses on the following dimensions: (i) to evaluate how researchers utilize RS data for assessing UES; (ii) to identify the dominant orientations regarding remotely sensed data sources; and (iii) to categorize the methodological constructs relied upon for evaluations.

\section{Methodology}

The methodological framework of the present study is based on the systematic review of literature. For this purpose, those research publications which utilized RS for assessing 
UES were identified through the Web of Science (WOS) (www.webofknowledge.com, accessed on 22 December 2020). The authors retrieved a total of 261 records of research articles against the search term "urban ecosystem services" published from January 2010 to December 2020. In retrospect and on a first perusal, it would appear that the reliance on the keyword "UES" has compromised the validity of findings by excluding studies of a similar nature but with different terminologies. However, the identification of publication through one keyword based on an "umbrella term" curtails subjectivity $[35,36]$, prevents digressions [13], and minimizes the impacts of irrelevant (false-positive) results [37]. For this purpose, Atif et al. [4] has successfully deployed this very technique regarding their investigations pertaining to UES. However, the current investigation is inherently different as it exclusively assesses the reliance on remotely sensed data in contemporary UES studies.

It is pertinent to mention that only those records were selected which were published or accepted for publication in the English language. However, review papers were excluded from the count for ensuring objectivity. The information was processed by deploying a two-tier cascading arrangement. Firstly, those publications were identified which had the term "Urban Ecosystem Services" in the title, abstract, or keywords. Subsequently, in the second phase only those articles were selected which rely on remotely sensed data (Figure 1). Based on that mechanism, 79 records qualified for further processing and content analysis (Table A1).

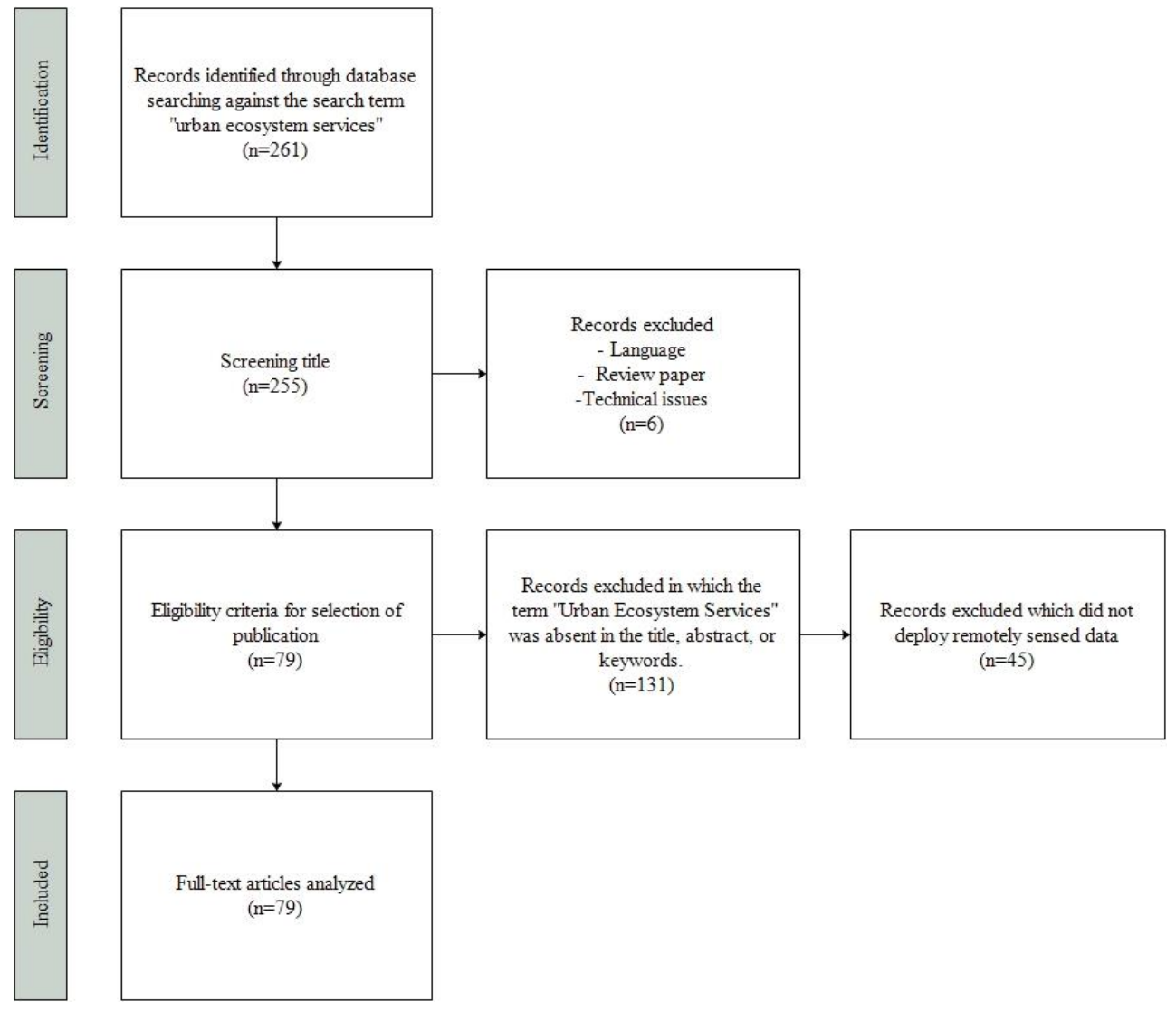

Figure 1. Flow chart for review of literature.

The significant findings pertaining to: (i) the type of ES being focused; (ii) the nature of RS dataset(s)/the purpose of assessment; and (iii) methodology(s) deployed for investigation identified and portrayed through Dendrogram (Figure 11). The scheme is preferred for spotting similarities and differences among/between strategies employed for assessments by Booth et al. [38]. 


\section{Results}

\subsection{The RS and UES Research}

The findings transpire that $29.89 \%$ of the total retrieved records $(n=261)$ relied on RS data for assessing UES. Significant inter and intra-continental differences were observed regarding the use of RS (Figures 2 and 3). The findings formulate that remotely sensed data-based research contributions from the European context $(58.97 \%)$ are the highest. It transpired that the proportionate shares from the remaining continents were negligible as compared to their volume of urbanization (Figure 3). The majority of reviewed publications $(96.15 \%)$ ) were planned in industrialized and developed regions, whereas the share from the developing hemisphere turned out to be quite miniscule $(3.85 \%)$. It reflects the prevalent schism between the global "North and South" in this domain as well. The findings corroborate the notions rendered by Atif et al. [4] and Akhtar et al. [13], that such differences are linked to economic, scientific, and technological advancements.

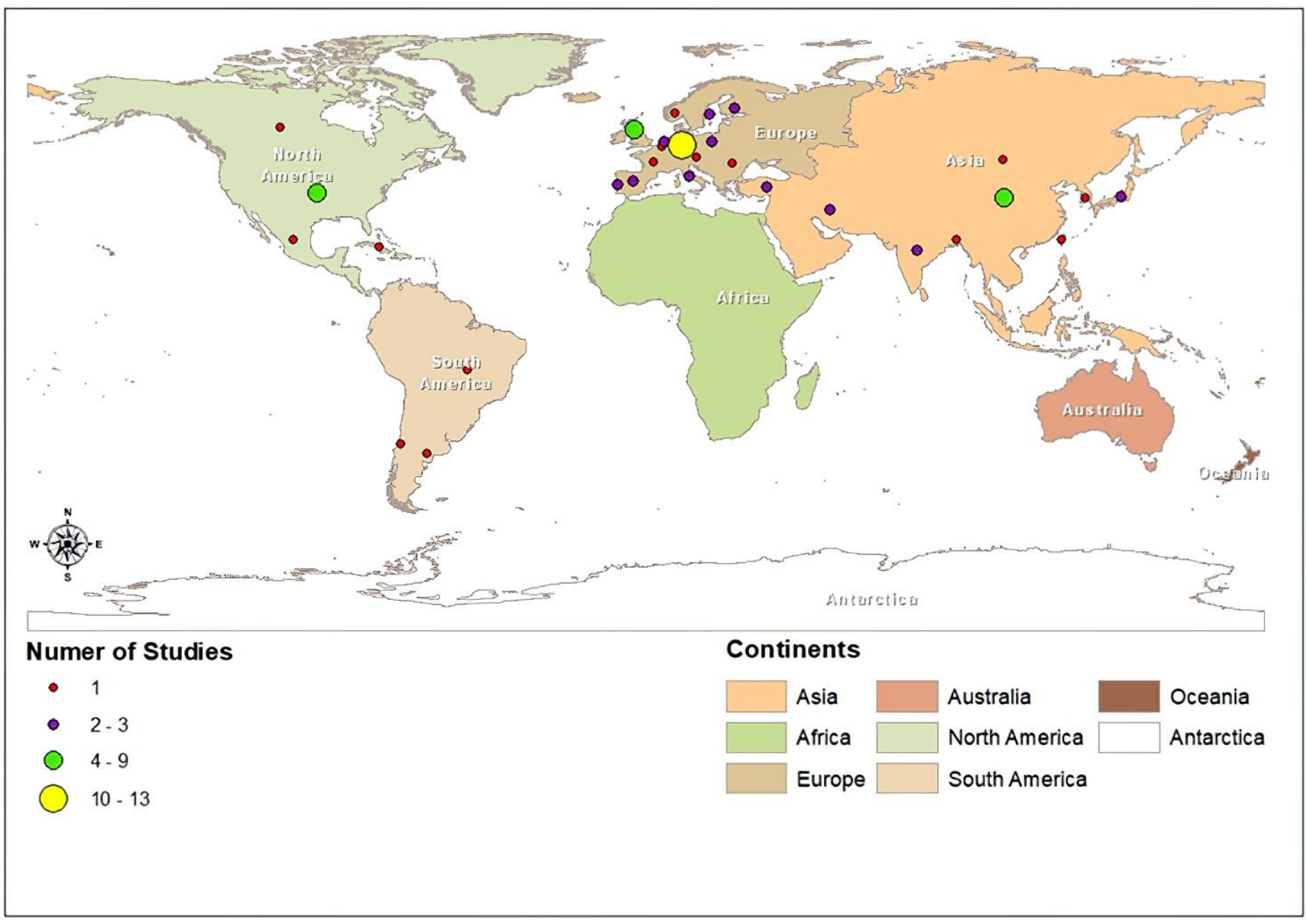

Figure 2. The spatial distribution of reviewed studies. 


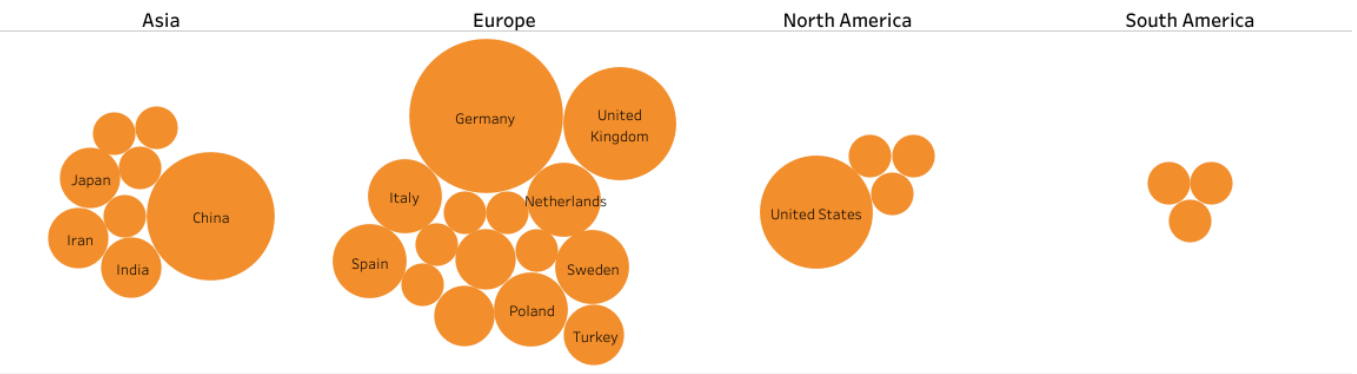

Figure 3. Continent-wise apportionment of reviewed studies.

\subsection{Temporal Fluctuations in Tendencies}

For assessing temporal fluctuations, the data (79 publications) were assessed. The available data were compartmentalized into two arbitrarily selected time intervals, i.e., 2010-2015 and 2016-2020. The largest number of publications appeared in the year 2016 $(n=14)$. The findings (Figure 4 ) depict that during the early phases of the first selected time interval (2010-2015), there was a growing tendency for RS. However, during the later phase (2016-2020), observable oscillations are evident in the proportionate share of different years, such as 2017 (15.19\%), 2018 (16.46\%), 2019(8.86\%), to 2020 (13.92\%). Atif et al. [4] also reported such tendencies based upon their investigation.

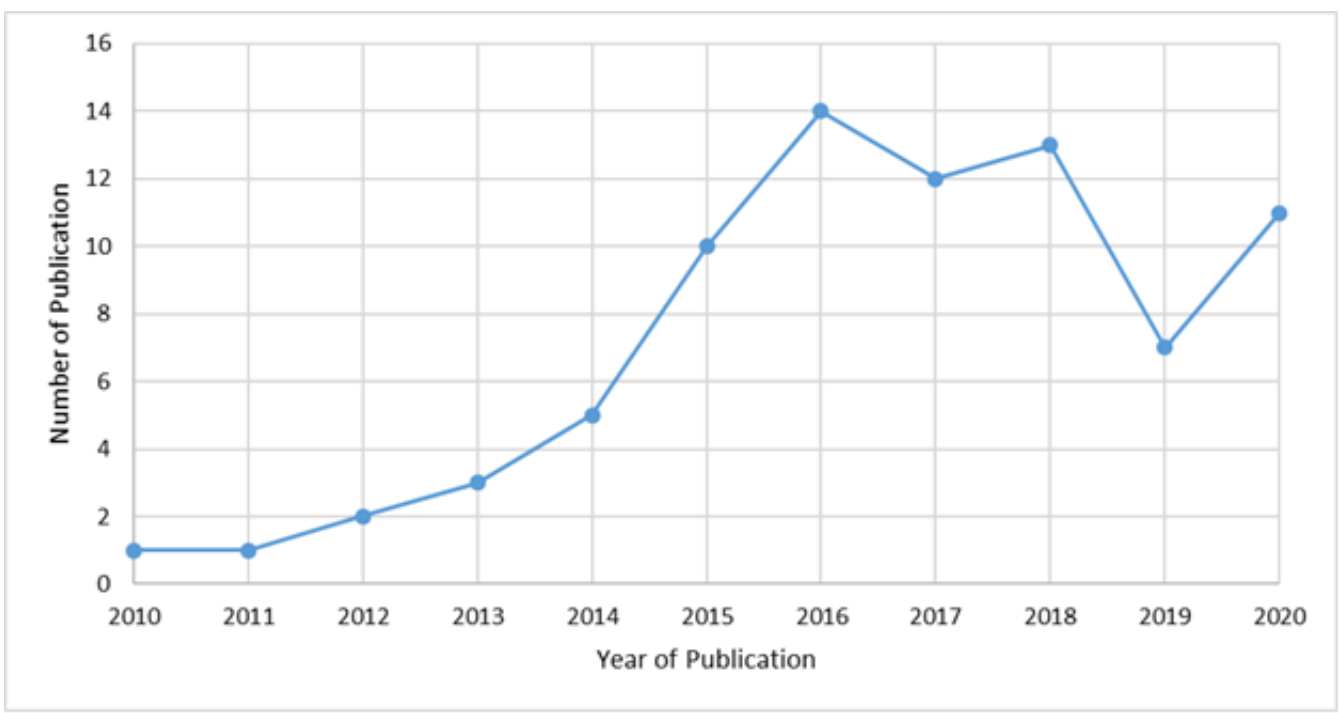

Figure 4. Temporal distribution of reviewed publications (2010-2020).

\subsection{Remote Sensing Data Sources and UES}

Research orientations regarding types of ES and Ecosystem Disservices (ED) were assessed (Figure 5). For the purpose of deciphering the linkages/interconnectedness between different ES services, the pair-based assessment technique was employed (Figure 6). The majority of the studies $(n=55)$ were adjudged to be cumulative assessments of four designated types of ES services. However, inclinations were observed to be more skewed towards regulating services as compared to cultural, provisioning, and supporting services. 


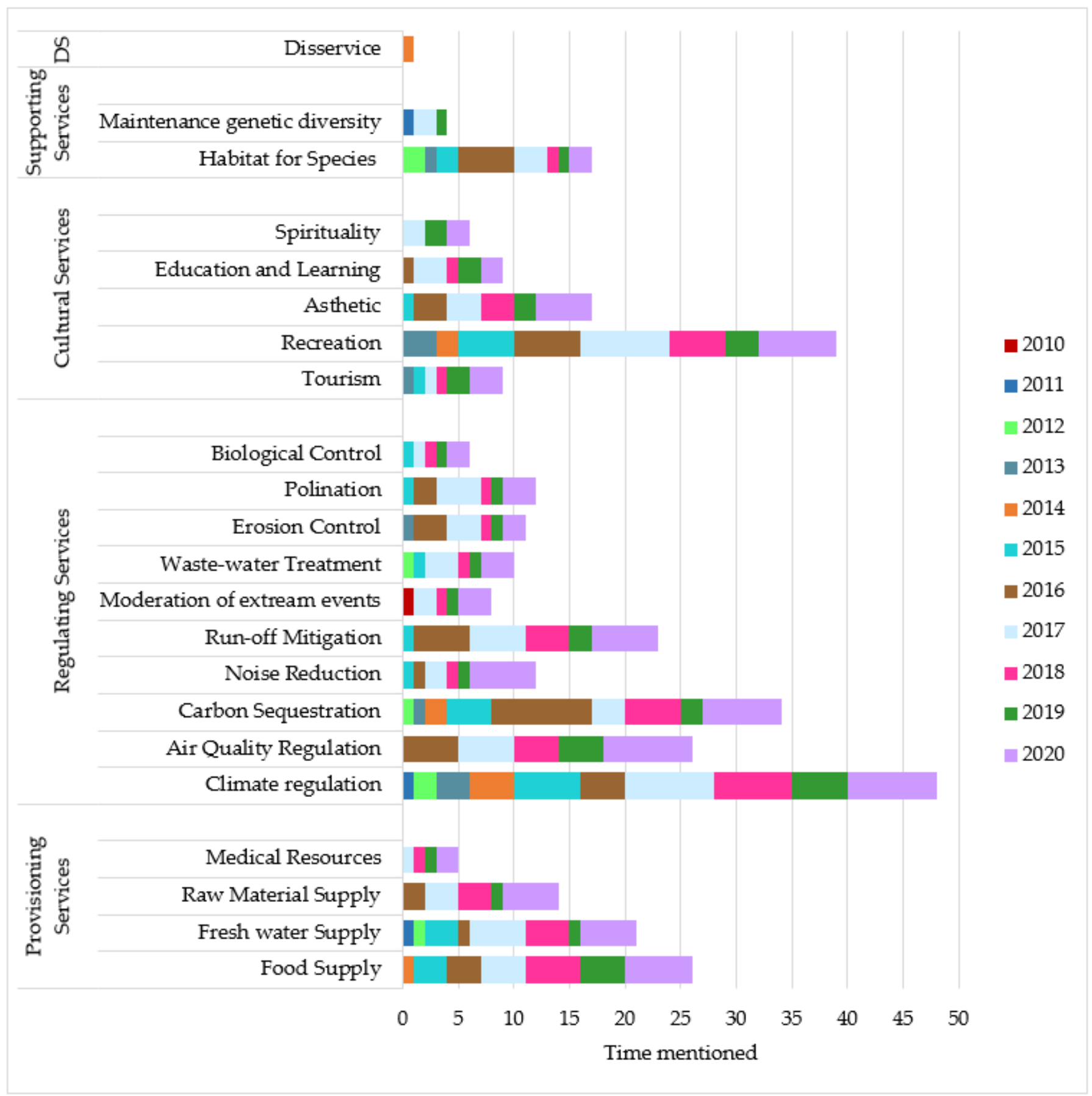

Figure 5. Types of UES and reviewed publications during 2010-2020.

Figure 7 portrays the frequency of data sources relied upon for data acquisition and Figure 8 illustrates their year-wise contribution. It transpired that most studies relied on no-cost/open data sources, such as Landsat family, MODIS, SPOT, etc., for assessing UES. Satellite-based optical sensors were preferred over image sensors, such as TIR, SAR, or light sensors for acquiring data. Open and free data resources, such as aerial orthophotos and Google Earth imagery are mainly consulted for land use classification and data validation. The information was integrated with socio-economic and demographic data repositories for holistic appraisals. Subsequently, the evaluations were integrated with ecological inventories and portrayed in the form of urban atlas. 


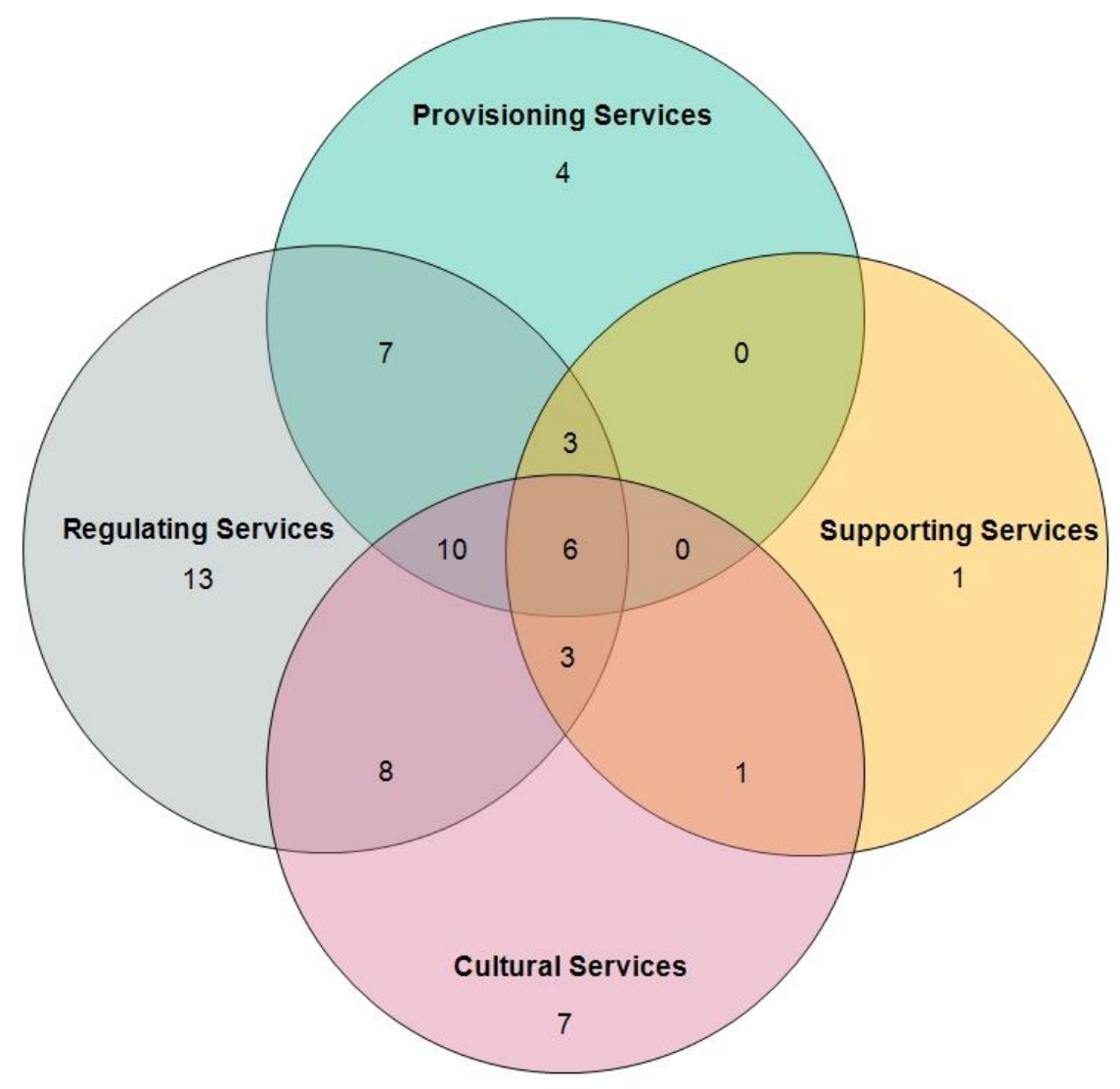

Figure 6. Pair based interconnectedness among UES.

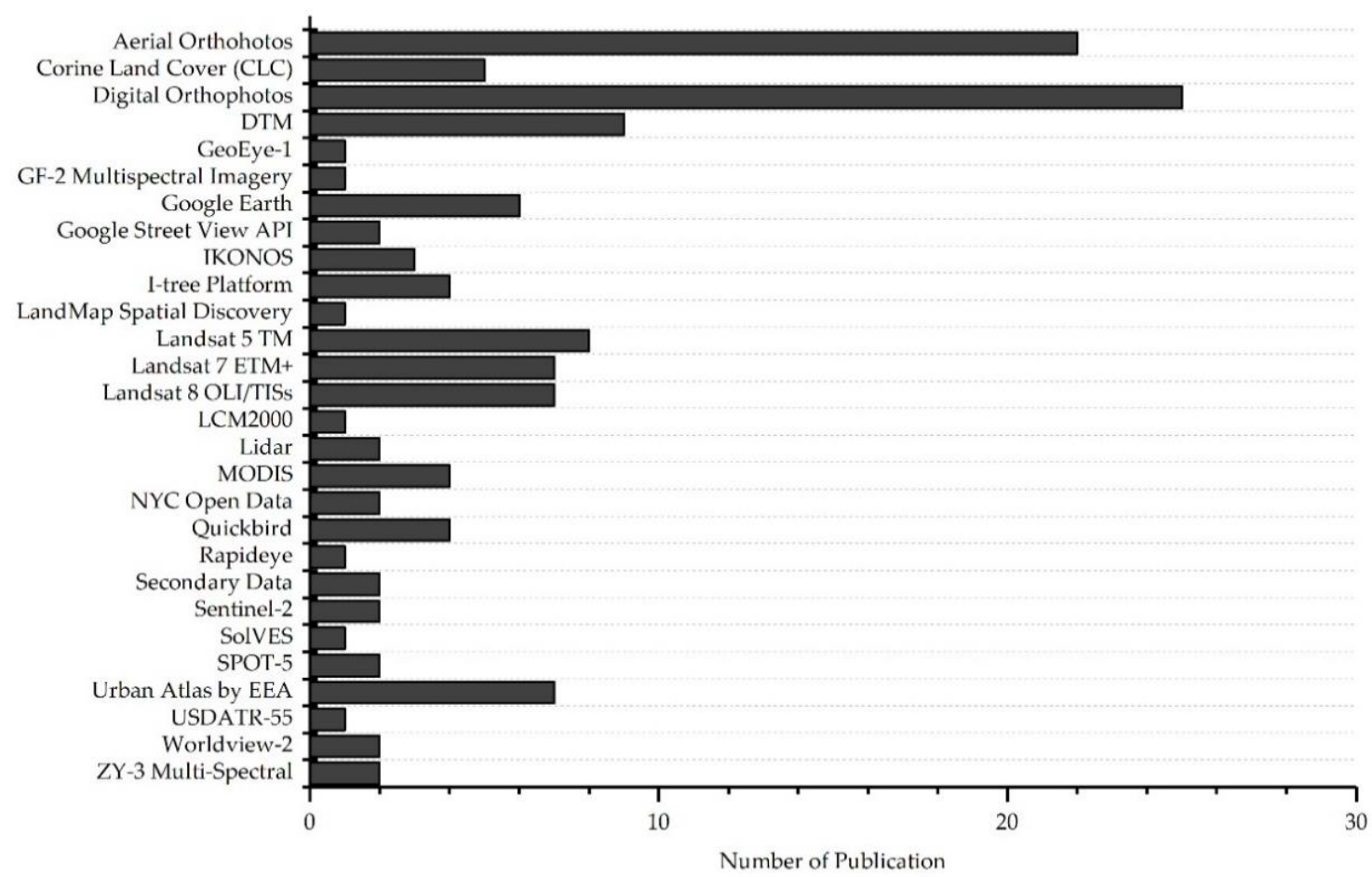

Figure 7. The frequency of data sources relied upon for assessments. 


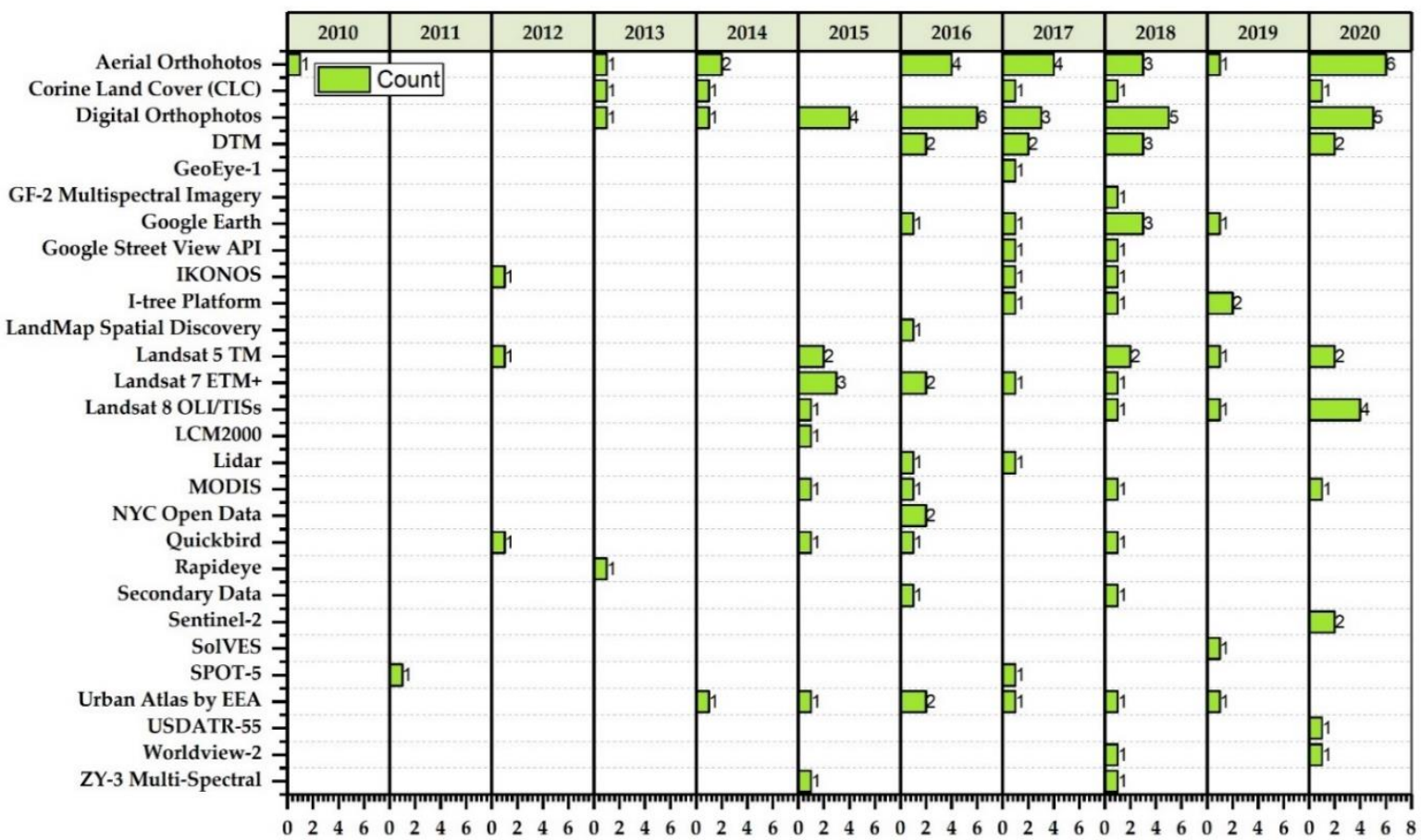

Figure 8. The year-wise contribution of data sources.

\subsection{Methodological Frameworks and RS}

UES are assessed by deploying multiple conceptual paradigms and approaches. The assessments (Figure 8) transpired that LULC-based technique was the preferred choice (59\%) for assessing UES. It is followed by the Normalized Difference Vegetation Index (NDVI) amounting to 23\%; Mapping Urban Tree (15\%); Land Surface Temperature (LST) method (11\%); the Green Canopy Cover technique (GCC) (6.3\%); and Normalized Difference Water Index (NDWI)-based parameters (3.8\%). Besides these methods, inVEST and mixed modelbased approaches are gaining recognition as well. A growing propensity for innovative measures, such as Linear Iterative Clustering (LIC); Normalized Digital Surface Model (nDSM); Convolutional Neural Networks (CNN) etc., was also noticed (Figures 9 and 10).

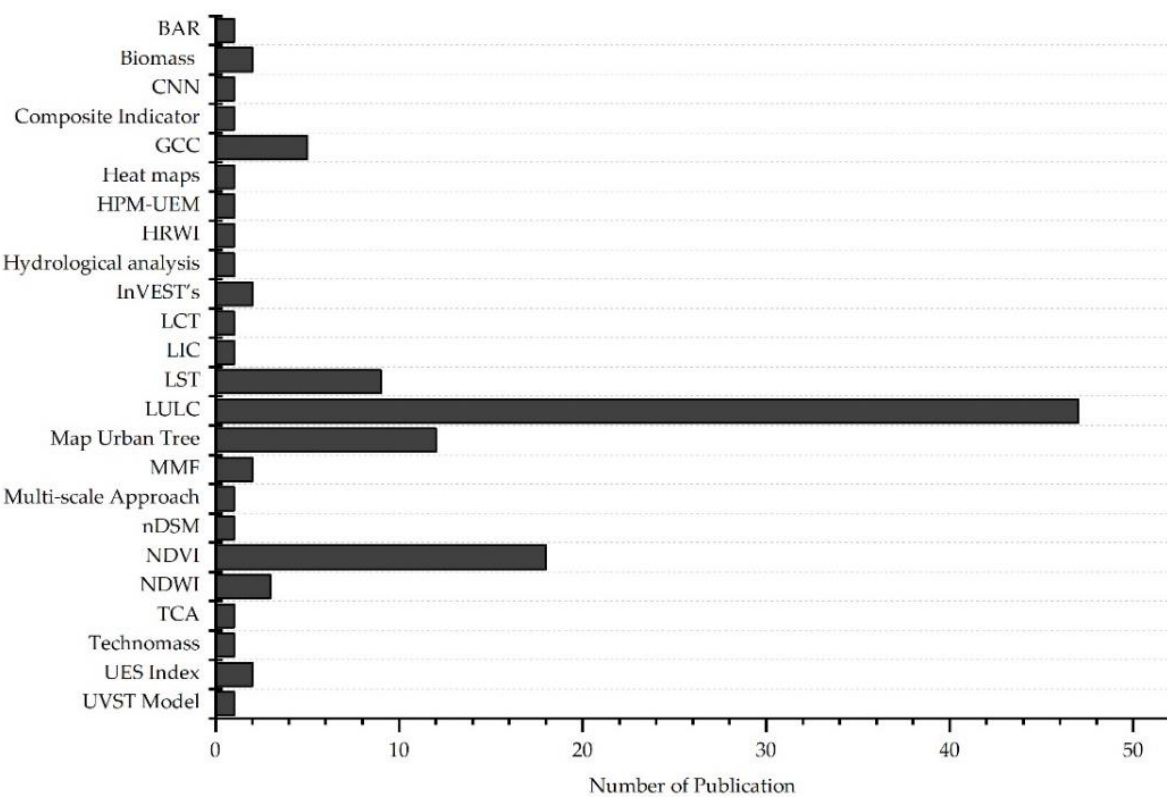

Figure 9. The frequency of methodological frameworks deployed for assessments. 


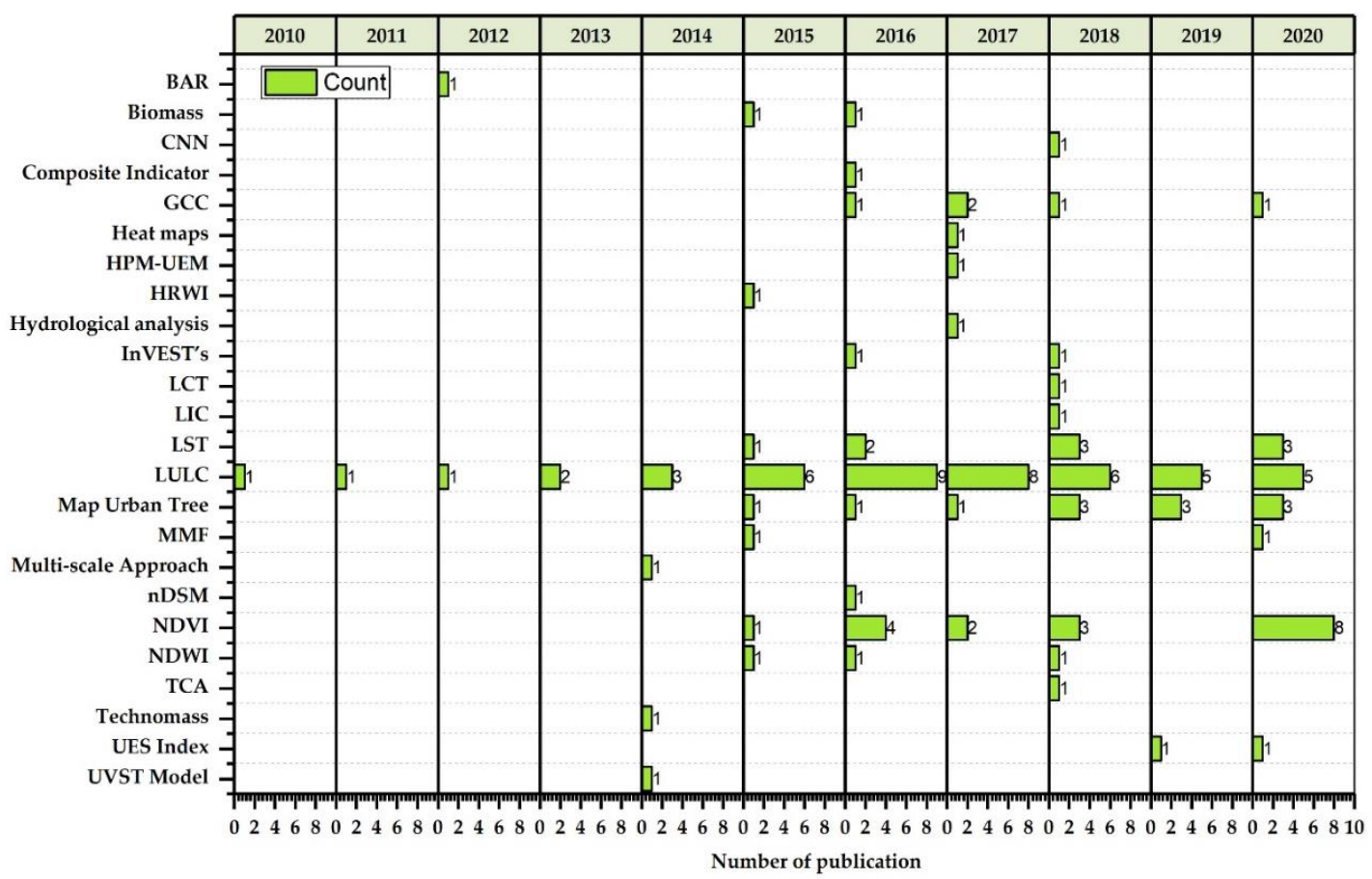

Figure 10. The year-wise contribution of methodological frameworks deployed for assessments.

For the purpose, similarities, and dissimilarities in data sources, methods and types of UES relied upon for assessments were adjudged. Figure 11 reflects the similarities/dissimilarities in orientations towards UES, based on the cluster analysis technique. It portrays a cascading hierarchy of clusters (Figure 11). The Dendrogram construes the presence of two notable sets of clusters (A and B) having $0 \%$ similarity between them. The difference is attributable to the type of urban ecosystem services selected/relied upon for assessments in the selected publications. The intra group variations were observed more noticeably in group A as compared to group B. It formulates that the publications in group A were designed from divergent perspectives, scales, and scopes for assessments. However, the reliance on LULC technique for assessing UES was recognized as a common feature in both the observed groupings.

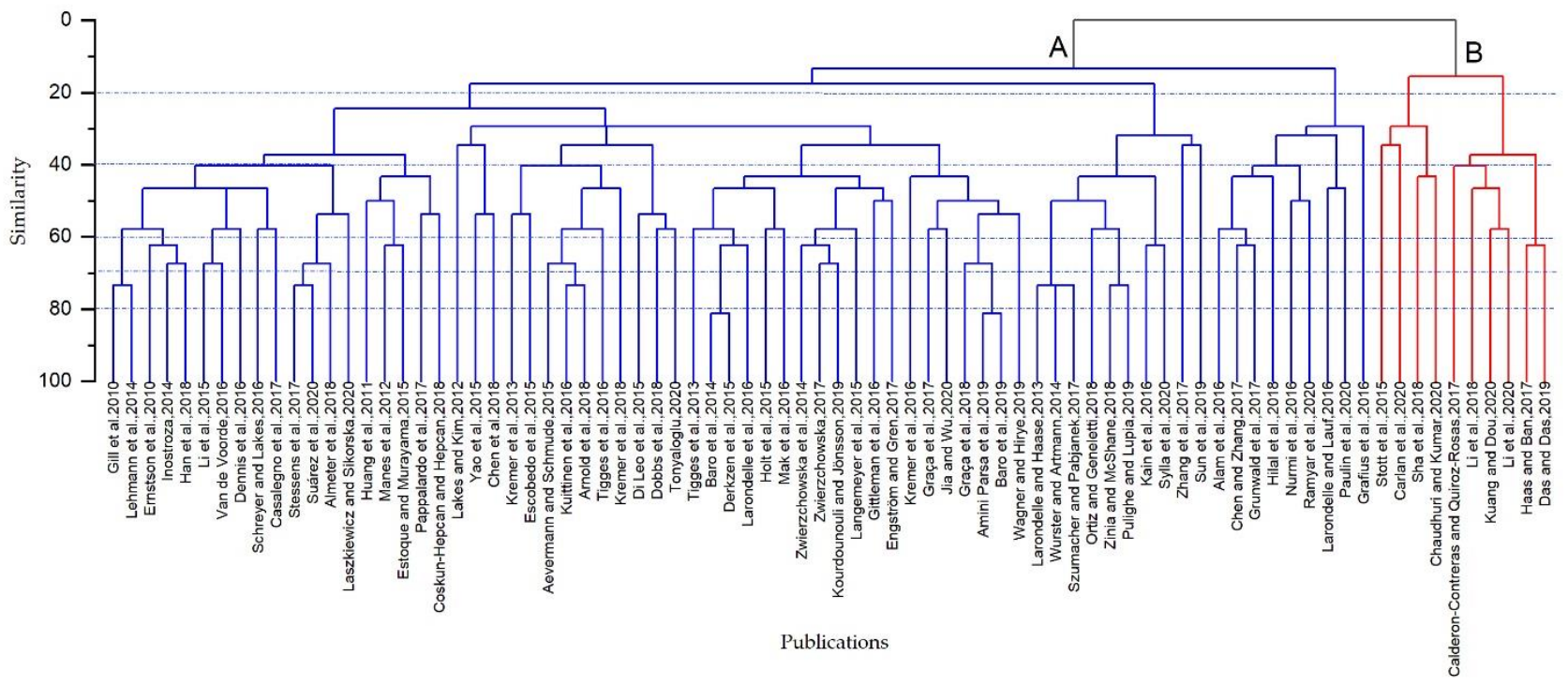

Figure 11. The similarities and differences among methodologies (Group A and Group B) and Cluster analysis technique. 


\section{Discussion}

The growing quantum of global urban population [39,40], the unprecedented expansions in urban areas [41], and associated ecological footprints are stressing people and their environment $[13,42]$. Stakeholders are improvising strategies for social, economic, and ecological resilience of urban life and infrastructure. For this purpose, the reliance on remotely sensed data for assessing, monitoring, and managing urban ecosystems and their services is gaining recognition $[8,43]$. The quantitative findings based on this investigation affirm that the reliance on RS and GIS is gaining recognition as tools for informed decision making. However, a significant decline in publications focusing on UES was noticed (Figure 4). The decline authenticates the reported observations that the propensities towards assessing UES are waning. Thus, the review of contemporary literature will serve as a barometer for assessing the causations and promoting scientific investigation regarding UES. The orientations are obligatory for realizing the objective of sustainability of urban environments.

The scrutiny of literature construed a delicate interplay between economic development and propensities towards environmental conservation. Whereas, whilst economic development encourages consumer culture, it simultaneously provides fiscal and technological support for ensuring environmental resilience. The findings (Figure 2.) surmise that the developed economies offer as more conducive playground for relying on RS in UES research. The spatial distribution of selected publications (Figures 2 and 3) authenticates the notions about economic development and proclivities towards UES research $[8,13,44]$. The gap in publications (Figure 3) between "the developed North" and "the developing south" supports the dictum that an empty stomach does not afford the luxury of a choice.

An increasing proportion of Asian scientists was observed focusing on UES in their published studies. The study also affirms that the share of Asia is more in published UES research as compared to the contributions from North America during the selected time interval (2000-2020). The observations are contrary to the assessments rendered by [43,45], but authenticate the robustness of conclusions of de Araujo Barbosa et al. [43]. The plausible explanation is rooted in the paradigm of "economic growth" and its trickle-down effects. The reported and projected estimates about urban demography and concomitant urban-centric economic developments in Asia [14,16] are pushing for urban ecological sustainability. Consequently, researchers are focusing on and improvising measures for ensuring socio-economic and environmental integrity of urban areas. However, Europe was observed in the leading role according to the assessment criteria of this study. The early exposure to urban environmental degradation, access to advanced technologies, and urban-based economic development spurred "environmentalism" in Europe [46,47]. The European exposure to early industrialization and its aftermaths helped to acknowledge the significance of nature and its contribution [48]. These stimulators encouraged urban environmental sustainability. These concomitant dividends are pouring out in the form of scholastic initiatives and publications.

Critical findings (Figures 7 and 8) transpired that the majority of studies relied on no-cost "open data sources". Landsat, MODIS, and SPOT families were most frequently consulted for data acquisition. For this purpose, the majority of studies relied on the open and free data repositories, such as aerial ortho-photos and Google Earth imageries. The information was subsequently processed, analyzed, and portrayed through GIS environment. It is pertinent to mention here that the majority of these selected studies were carried out in economically and technologically developed regions (Figures 2 and 3). On the contrary, the lack of resources for capacity building in developing regions retard the exposure, experience, and expertise of researchers; therefore, they rely less on these gadgets, i.e., RS and GIS. It surmises the hardships being faced by the academia and research fraternities in the less developed parts of the globe. Moreover, the restrictions to access/consult scholarly contributions due to "financial/monetary" constraints discourage their utilization in the fragile and resource-parched economies. 
The assessments rendered that reliance on secondary data sources in the studies focusing on UES is a preferred choice among researchers. The observation corroborated the notion rendered by Tavares et al. [49], that RS facilitates data acquisitions for ecological studies. Reliance over RS ensures time and cost effectiveness. For this purpose, Landsat and Sentinel satellite families are frequently consulted (Figures 9 and 10). This predisposition is an outcome of accessibility, availability, and cost factors [49,50]. Moreover, the data aggregation of Landsat and Sentinel families is possible and required for deciphering longterm oscillations in the natural environment [51], whereas high-resolution images, such as SPOT-5 [52,53], aerial and digital orthophotos [54-56], Worldview-2 [57,58], RapidEye imagery [59], GeoEye [60], IKONOS [60,61], and Quickbird [61-63] are considered as more reliable options for evaluating UES. However, the utilization of these repositories depends on the accessibility and availability of financial resources.

The findings formulate that regulating services are more focused on research, as compared to other categories of UES, while the content analysis revealed that the LULC evaluation based on RS data is a widely deployed mechanism for assessing UES [64-67]. The tendencies are gaining recognition due to objective, accurate, and user-friendly orientations of this mechanism. Recent advances in associated techniques (such as NDVI, LAI, LST, NDWI, and TCA) are providing more objectivity to LULC assessments [62,65,68-70]. The cluster analysis (Figure 11) corroborates the reported assertions of $[8,49,71]$ that LULC assessments deftly infer about the fluctuations in UES. Growing exposure, experiences, and expertise are popularizing and giving impetus to the use of remotely sensed data in ecological studies [72,73]. However, growing restrictions on data acquisition [49] are posing newfound challenges for developing economies. The scenario entails for constructive support from developed to developing regions for global environmental security.

The observations underline the need for an out-of-the-box solution for this dichotomous situation. While the mechanics of the market economy operate on the premises of profit, the ecological health of the planet earth calls for cost-effective holistic interventions. It requires a sustainable solution with the support of developed economies and donors in the light of climate and justice debate. The cost-free dissemination of knowledge and sharing of experiences will symptomatically contribute towards capacity building. This stimulator will encourage the intended orientations towards urban green infrastructure in developing regions. Intellectual collaboration and funding are vitally required for informed assessments/decision making regarding urban ecological resources. A paradigm shift based on the principle of knowledge sharing will serve as a catalyst for transforming perceptions regarding the environment in such contextual settings.

\section{Conclusions}

Urbanization and modifications in urban areas are stressing the urban environment. Holistic appraisals of concomitant impacts on UES are imperative for informed decision making to ensure the resilience of urban life. The critical findings of this investigation authenticate the assertions that accessibility, availability, and cost of data and analysis are the crucial factors considered by the researchers. The findings of this review contemplate that the focus of contemporary studies regarding urban areas is drifting from interpretation to knowledge acquisition for informed decision making. For this purpose, reliance on RS and GIS is gaining recognition. The inclinations were observed more directed towards assessing regulating services, when compared to other categories of ES. Besides this, the LULC-based assessment technique is commonly deployed for evaluating UES. The assessments affirm that an overwhelmingly larger share of UES research comes from the developed world. Researchers from developed and developing countries prefer a no-cost or open data sources for investigating UES. Meanwhile, difficulties in data accessibility, the lack of availability of RS and GIS-based software, and the absence of capacity building measures in developing countries is impeding all research momentum. Consequently, the reliance on remotely sensed data is waning. It entails for "out of the box" measures for stimulating RS-based UES research in the transforming economies. Availability of 
open-ware tools, such as Google Earth Engine and cost-free access to databases, allied with other capacity building measures, are vitally required.

Author Contributions: Conceptualization, M.Z.-u.-H., Z.S., A.K., S.N. and M.S.; methodology, H.H., N.A., S.A.B. and A.I.; software, M.Z.-u.-H., Z.S., A.K., S.N. and M.S.; validation, H.H., N.A., S.A.B. and A.I.; formal analysis, M.Z.-u.-H., Z.S., A.K., S.N. and M.S.; investigation, H.H., N.A., S.A.B. and A.I.; resources and data curation, M.Z.-u.-H., Z.S., A.K., S.N. and M.S.; writing-original draft preparation, M.Z.-u.-H., Z.S., A.K., S.N. and M.S.; writing-review and editing, H.H., N.A., S.A.B. and A.I.; visualization, M.Z.-u.-H., Z.S., A.K., S.N. and M.S.; supervision, A.I. and H.H., project administration, A.I., M.S. and S.A.B. All authors have read and agreed to the published version of the manuscript.

Funding: The author thanks Natural Sciences and Engineering Research Council of Canada (NSERC) and New Brunswick Innovation Foundation (NBIF) for the financial support of the global project. These granting agencies did not contribute in the design of the study and collection, analysis, and interpretation of data.

Institutional Review Board Statement: Not applicable.

Informed Consent Statement: Not applicable.

Data Availability Statement: Not applicable.

Conflicts of Interest: The authors declare no conflict of interest. 


\section{Appendix A}

Table A1. List of the articles used for systematic literature review.

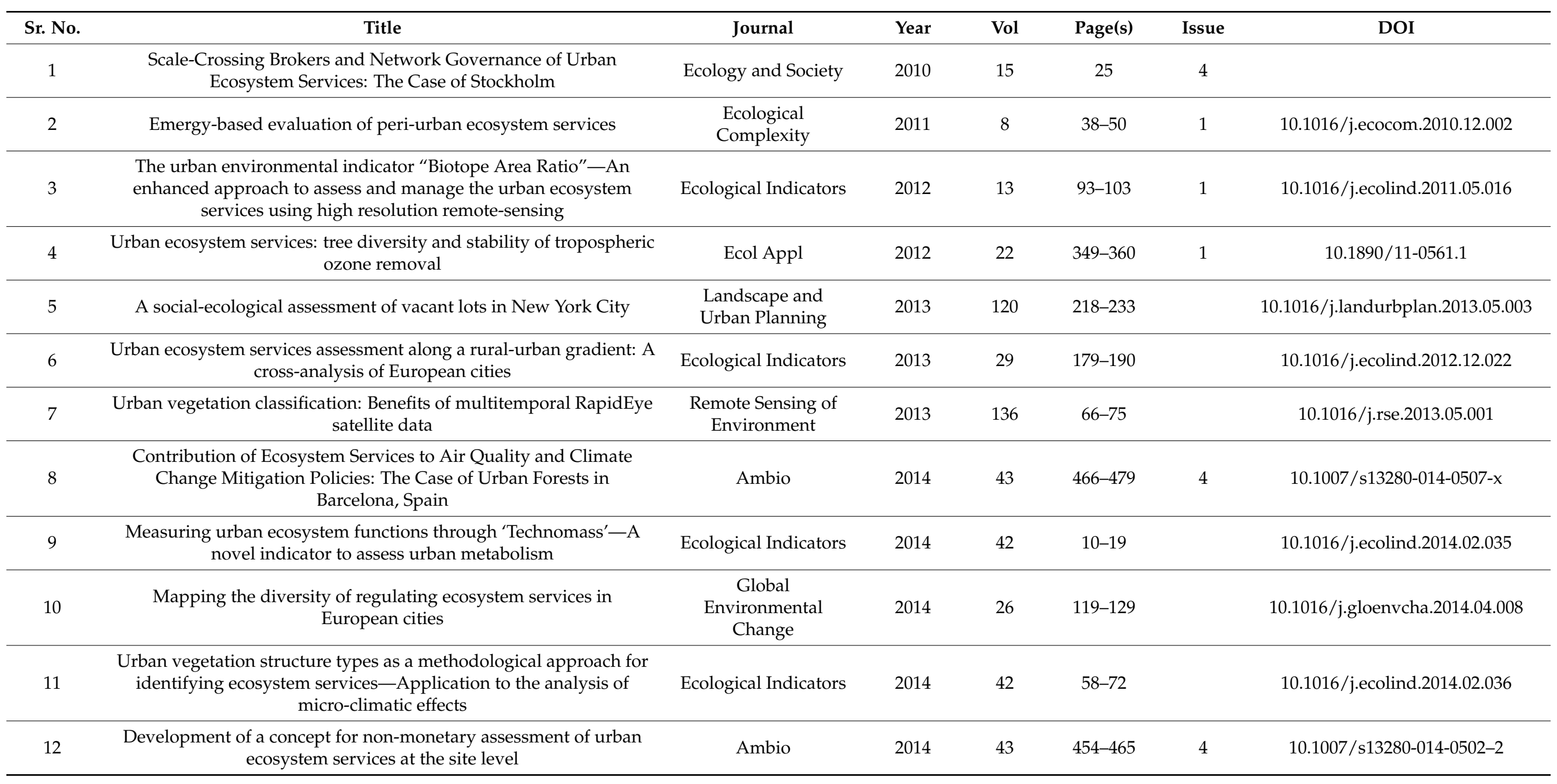


Table A1. Cont.

\begin{tabular}{|c|c|c|c|c|c|c|c|}
\hline Sr. No. & Title & Journal & Year & Vol & Page(s) & Issue & DOI \\
\hline 13 & $\begin{array}{l}\text { Quantification and monetary valuation of urban ecosystem services } \\
\text { in Munich, Germany }\end{array}$ & $\begin{array}{l}\text { Zeitschrift Fur } \\
\text { Wirtschaftsgeogra- } \\
\text { phie }\end{array}$ & 2015 & 59 & $188-200$ & 3 & \\
\hline 14 & $\begin{array}{l}\text { REVIEW: Quantifying urban ecosystem services based on } \\
\text { high-resolution data of urban green space: an assessment for } \\
\text { Rotterdam, the Netherlands }\end{array}$ & $\begin{array}{l}\text { Journal of Applied } \\
\text { Ecology }\end{array}$ & 2015 & 52 & 1020-1032 & 4 & $10.1111 / 1365-2664.12469$ \\
\hline 15 & $\begin{array}{l}\text { The role of urban green infrastructure in mitigating land surface } \\
\text { temperature in Bobo-Dioulasso, Burkina Faso }\end{array}$ & $\begin{array}{l}\text { Environment, } \\
\text { Development and } \\
\text { Sustainability }\end{array}$ & 2015 & 18 & $373-392$ & 2 & $10.1007 /$ s10668-015-9653-y \\
\hline 16 & $\begin{array}{l}\text { Socio-ecological dynamics and inequality in Bogotá, Colombia's } \\
\text { public urban forests and their ecosystem services }\end{array}$ & $\begin{array}{l}\text { Urban Forestry \& } \\
\text { Urban Greening }\end{array}$ & 2015 & 14 & $1040-1053$ & 4 & 10.1016/j.ufug.2015.09.011 \\
\hline 17 & $\begin{array}{l}\text { Intensity and spatial pattern of urban land changes in the megacities } \\
\text { of Southeast Asia }\end{array}$ & Land Use Policy & 2015 & 48 & $213-222$ & & 10.1016/j.landusepol.2015.05.017 \\
\hline 18 & $\begin{array}{l}\text { Understanding spatial patterns in the production of multiple urban } \\
\text { ecosystem services }\end{array}$ & Ecosystem Services & 2015 & 16 & $33-46$ & & 10.1016/j.ecoser.2015.08.007 \\
\hline 19 & $\begin{array}{l}\text { Contrasting values of cultural ecosystem services in urban areas: The } \\
\text { case of park Montjuïc in Barcelona }\end{array}$ & Ecosystem Services & 2015 & 12 & $178-186$ & & 10.1016/j.ecoser.2014.11.016 \\
\hline 20 & $\begin{array}{l}\text { A comparison of the economic benefits of urban green spaces } \\
\text { estimated with NDVI and with high-resolution land cover data }\end{array}$ & $\begin{array}{l}\text { Landscape and } \\
\text { Urban Planning }\end{array}$ & 2015 & 133 & $105-117$ & & 10.1016/j.landurbplan.2014.09.013 \\
\hline 21 & Land sparing is crucial for urban ecosystem services & $\begin{array}{l}\text { Frontiers in Ecology } \\
\text { and the Environment }\end{array}$ & 2015 & 13 & $387-393$ & 7 & $10.1890 / 140286$ \\
\hline 22 & $\begin{array}{c}\text { High-Resolution Mapping of Urban Surface Water Using ZY-3 } \\
\text { Multi-Spectral Imagery }\end{array}$ & Remote Sensing & 2015 & 7 & $\begin{array}{l}12,336- \\
12,355\end{array}$ & 9 & $10.3390 /$ rs70912336 \\
\hline 23 & $\begin{array}{l}\text { A framework towards a composite indicator for urban } \\
\text { ecosystem services }\end{array}$ & Ecological Indicators & 2016 & 60 & $38-44$ & & 10.1016/j.ecolind.2015.05.035 \\
\hline 24 & $\begin{array}{l}\text { Appraisal of social-ecological innovation as an adaptive response by } \\
\text { stakeholders to local conditions: Mapping stakeholder involvement } \\
\text { in horticulture orientated green space management }\end{array}$ & $\begin{array}{l}\text { Urban Forestry \& } \\
\text { Urban Greening }\end{array}$ & 2016 & 18 & $86-94$ & & 10.1016/j.ufug.2016.05.010 \\
\hline 25 & $\begin{array}{l}\text { Estimating stormwater runoff for community gardens in New } \\
\text { York City }\end{array}$ & Urban Ecosystems & 2016 & 20 & 129-139 & 1 & $10.1007 / \mathrm{s} 11252-016-0575-8$ \\
\hline
\end{tabular}


Table A1. Cont.

\begin{tabular}{|c|c|c|c|c|c|c|c|}
\hline Sr. No. & Title & Journal & Year & Vol & Page(s) & Issue & DOI \\
\hline 26 & $\begin{array}{l}\text { The impact of land use/land cover scale on modelling urban } \\
\text { ecosystem services }\end{array}$ & Landscape Ecology & 2016 & 31 & $1509-1522$ & 7 & $10.1007 / \mathrm{s} 10980-015-0337-7$ \\
\hline 27 & $\begin{array}{l}\text { Exploring local consequences of two land-use alternatives for the } \\
\text { supply of urban ecosystem services in Stockholm year } 2050\end{array}$ & Ecological Indicators & 2016 & 70 & $615-629$ & & 10.1016/j.ecolind.2016.02.062 \\
\hline 28 & $\begin{array}{l}\text { The value of urban ecosystem services in New York City: A spatially } \\
\text { explicit multicriteria analysis of landscape scale valuation scenarios }\end{array}$ & $\begin{array}{l}\text { Environmental } \\
\text { Science \& Policy }\end{array}$ & 2016 & 62 & $57-68$ & & 10.1016/j.envsci.2016.04.012 \\
\hline 29 & $\begin{array}{l}\text { Carbon sequestration through urban ecosystem services: A case study } \\
\text { from Finland }\end{array}$ & Sci Total Environ & 2016 & $\begin{array}{l}563- \\
564\end{array}$ & $623-632$ & & 10.1016/j.scitotenv.2016.03.168 \\
\hline 30 & $\begin{array}{l}\text { Mapping transition potential with stakeholder- and policy-driven } \\
\text { scenarios in Rotterdam City }\end{array}$ & Ecological Indicators & 2016 & 70 & $630-643$ & & 10.1016/j.ecolind.2016.02.028 \\
\hline 31 & $\begin{array}{l}\text { Balancing demand and supply of multiple urban ecosystem services } \\
\text { on different spatial scales }\end{array}$ & Ecosystem Services & 2016 & 22 & $18-31$ & & 10.1016/j.ecoser.2016.09.008 \\
\hline 32 & $\begin{array}{l}\text { Sustainable drainage system site assessment method using urban } \\
\text { ecosystem services }\end{array}$ & Urban Ecosystems & 2016 & 20 & $293-307$ & 2 & $10.1007 / \mathrm{s} 11252-016-0593-6$ \\
\hline 33 & $\begin{array}{c}\text { Green Roof Cost-Benefit Analysis: Special Emphasis on Scenic } \\
\text { Benefits }\end{array}$ & $\begin{array}{c}\text { Journal of } \\
\text { Benefit-Cost Analysis }\end{array}$ & 2016 & 7 & $488-522$ & 3 & 10.1017/bca.2016.18 \\
\hline 34 & $\begin{array}{l}\text { Deriving and Evaluating City-Wide Vegetation Heights from a } \\
\text { TanDEM-X DEM }\end{array}$ & Remote Sensing & 2016 & 8 & 940 & 11 & $10.3390 /$ rs8110940 \\
\hline 35 & $\begin{array}{l}\text { Modeling above-ground carbon storage: a remote sensing approach } \\
\text { to derive individual tree species information in urban settings }\end{array}$ & Urban Ecosystems & 2016 & 20 & $97-111$ & 1 & $10.1007 / \mathrm{s} 11252-016-0585-6$ \\
\hline 36 & $\begin{array}{l}\text { Spatially explicit urban green indicators for characterizing vegetation } \\
\text { cover and public green space proximity: a case study on Brussels, } \\
\text { Belgium }\end{array}$ & $\begin{array}{l}\text { International Journal } \\
\text { of Digital Earth }\end{array}$ & 2016 & 10 & $798-813$ & 8 & $10.1080 / 17538947.2016 .1252434$ \\
\hline 37 & $\begin{array}{l}\text { Analysing scale, quality and diversity of green infrastructure and the } \\
\text { provision of Urban Ecosystem Services: A case from Mexico City }\end{array}$ & Ecosystem Services & 2017 & 23 & $127-137$ & & 10.1016/j.ecoser.2016.12.004 \\
\hline 38 & $\begin{array}{l}\text { Improving models of urban greenspace: from vegetation surface } \\
\text { cover to volumetric survey, using waveform laser scanning }\end{array}$ & $\begin{array}{l}\text { Methods in Ecology } \\
\text { and Evolution }\end{array}$ & 2017 & 8 & $1443-1452$ & 11 & 10.1111/2041-210x.12794 \\
\hline
\end{tabular}


Table A1. Cont.

\begin{tabular}{|c|c|c|c|c|c|c|c|}
\hline Sr. No. & Title & Journal & Year & Vol & Page(s) & Issue & DOI \\
\hline 39 & $\begin{array}{c}\text { Projecting the CO2 and Climatic Change Effects on the Net Primary } \\
\text { Productivity of the Urban Ecosystems in Phoenix, AZ in the 21st } \\
\text { Century under Multiple RCP (Representative Concentration } \\
\text { Pathway) Scenarios }\end{array}$ & Sustainability & 2017 & 9 & 1366 & 8 & $10.3390 / \mathrm{su} 9081366$ \\
\hline 40 & $\begin{array}{l}\text { Capturing the value of green space in urban parks in a sustainable } \\
\text { urban planning and design context: pros and cons of hedonic pricing }\end{array}$ & Ecology and Society & 2017 & 22 & 13 & 2 & $10.5751 /$ es-09365-220221 \\
\hline 41 & $\begin{array}{l}\text { Assessing mismatches in ecosystem services proficiency across the } \\
\text { urban fabric of Porto (Portugal): The influence of structural and } \\
\text { socioeconomic variables }\end{array}$ & Ecosystem Services & 2017 & 23 & $82-93$ & & 10.1016/j.ecoser.2016.11.015 \\
\hline 42 & $\begin{array}{l}\text { A GIS-based mapping methodology of urban green roof ecosystem } \\
\text { services applied to a Central European city }\end{array}$ & $\begin{array}{l}\text { Urban Forestry \& } \\
\text { Urban Greening }\end{array}$ & 2017 & 22 & $54-63$ & & 10.1016/j.ufug.2017.01.001 \\
\hline 43 & $\begin{array}{l}\text { Mapping and Monitoring Urban Ecosystem Services Using } \\
\text { Multitemporal High-Resolution Satellite Data }\end{array}$ & $\begin{array}{l}\text { IEEE Journal of } \\
\text { Selected Topics in } \\
\text { Applied Earth } \\
\text { Observations and } \\
\text { Remote Sensing }\end{array}$ & 2017 & 10 & $669-680$ & 2 & 10.1109 /jstars.2016.2586582 \\
\hline 45 & $\begin{array}{l}\text { Analysing urban green space accessibility and quality: A GIS-based } \\
\text { model as spatial decision support for urban ecosystem services } \\
\text { in Brussels }\end{array}$ & Ecosystem Services & 2017 & 28 & $328-340$ & & 10.1016/j.ecoser.2017.10.016 \\
\hline 46 & $\begin{array}{l}\text { Temporal Changes in Ecosystem Services in European Cities in the } \\
\text { Continental Biogeographical Region in the Period from 1990-2012 }\end{array}$ & Sustainability & 2017 & 9 & 665 & 4 & $10.3390 /$ su9040665 \\
\hline 47 & $\begin{array}{l}\text { Ecological landscape regulation approaches in Xilingol, Inner } \\
\text { Mongolia: an urban ecosystem services perspective }\end{array}$ & $\begin{array}{l}\text { International Journal } \\
\text { of Sustainable } \\
\text { Development and } \\
\text { World Ecology }\end{array}$ & 2017 & 24 & $401-407$ & 5 & $10.1080 / 13504509.2016 .1273263$ \\
\hline
\end{tabular}


Table A1. Cont.

\begin{tabular}{|c|c|c|c|c|c|c|c|}
\hline Sr. No. & Title & Journal & Year & Vol & Page(s) & Issue & DOI \\
\hline 48 & $\begin{array}{l}\text { Urban ecosystem services-assessment of potential at the different } \\
\text { spatial scale: an example of poznan }\end{array}$ & $\begin{array}{l}\text { Ekonomia I } \\
\text { Srodowisko- } \\
\text { Economics and } \\
\text { Environment }\end{array}$ & 2017 & 1 & $207-225$ & 60 & \\
\hline 49 & $\begin{array}{c}\text { A Needs-Driven, Multi-Objective Approach to Allocate Urban } \\
\text { Ecosystem Services from 10,000 Trees }\end{array}$ & Sustainability & 2018 & 10 & 15 & 12 & $10.3390 /$ su10124488 \\
\hline 50 & $\begin{array}{c}\text { A Differentiated Spatial Assessment of Urban Ecosystem Services } \\
\text { Based on Land Use Data in Halle, Germany }\end{array}$ & Land & 2018 & 7 & 101 & 3 & 10.3390/land7030101 \\
\hline 51 & $\begin{array}{l}\text { Extraction of Urban Water Bodies from High-Resolution } \\
\text { Remote-Sensing Imagery Using Deep Learning }\end{array}$ & Water & 2018 & 10 & 585 & 5 & $10.3390 / w 10050585$ \\
\hline 52 & $\begin{array}{l}\text { Assessing ecosystem services of bornova's green infrastructure, } \\
\text { izmir (turkey) }\end{array}$ & $\begin{array}{l}\text { Fresenius } \\
\text { Environmental } \\
\text { Bulletin }\end{array}$ & 2018 & 27 & $3530-3541$ & $5 \mathrm{~A}$ & \\
\hline 53 & $\begin{array}{l}\text { Exploring temporal dynamics of urban ecosystem services in Latin } \\
\text { America: The case of Bogota (Colombia) and Santiago (Chile) }\end{array}$ & Ecological Indicators & 2018 & 85 & $1068-1080$ & & 10.1016/j.ecolind.2017.11.062 \\
\hline 54 & $\begin{array}{c}\text { Assessing how green space types affect ecosystem services delivery in } \\
\text { Porto, Portugal }\end{array}$ & $\begin{array}{l}\text { Landscape and } \\
\text { Urban Planning }\end{array}$ & 2018 & 170 & 195-208 & & 10.1016/j.landurbplan.2017.10.007 \\
\hline 55 & $\begin{array}{c}\text { Mapping and Quantifying Variations in Ecosystem Services of Urban } \\
\text { Green Spaces: A Test Case of Carbon Sequestration at the District } \\
\text { Scale for Seoul, Korea (1975-2015) }\end{array}$ & $\begin{array}{l}\text { International Review } \\
\text { for Spatial Planning } \\
\text { and Sustainable } \\
\text { Development }\end{array}$ & 2018 & 6 & $110-120$ & 3 & 10.14246/irspsd.6.3_110 \\
\hline 56 & Visual structure of landscapes seen from built environment & $\begin{array}{l}\text { Urban Forestry \& } \\
\text { Urban Greening }\end{array}$ & 2018 & 32 & $71-80$ & & 10.1016/j.ufug.2018.03.020 \\
\hline 57 & $\begin{array}{l}\text { Within-Class and Neighborhood Effects on the Relationship between } \\
\text { Composite Urban Classes and Surface Temperature }\end{array}$ & Sustainability & 2018 & 10 & 645 & 3 & $10.3390 /$ su10030645 \\
\hline 58 & $\begin{array}{c}\text { Study of the Spatiotemporal Variation Characteristics of Forest } \\
\text { Landscape Patterns in Shanghai from } 2004 \text { to } 2014 \text { Based on } \\
\text { Multisource Remote Sensing Data }\end{array}$ & Sustainability & 2018 & 10 & 4397 & 12 & $10.3390 /$ su10124397 \\
\hline 59 & $\begin{array}{c}\text { Assessing Mismatches in the Provision of Urban Ecosystem Services } \\
\text { to Support Spatial Planning: A Case Study on Recreation and Food } \\
\text { Supply in Havana, Cuba }\end{array}$ & Sustainability & 2018 & 10 & 2165 & 7 & $10.3390 /$ su10072165 \\
\hline
\end{tabular}


Table A1. Cont.

\begin{tabular}{|c|c|c|c|c|c|c|c|}
\hline Sr. No. & Title & Journal & Year & Vol & Page(s) & Issue & DOI \\
\hline 60 & $\begin{array}{l}\text { Mapping the Changes in Urban Greenness Based on Localized Spatial } \\
\text { Association Analysis under Temporal Context Using MODIS Data }\end{array}$ & $\begin{array}{l}\text { ISPRS International } \\
\text { Journal of } \\
\text { Geo-Information }\end{array}$ & 2018 & 7 & 407 & 10 & 10.3390/ijgi7100407 \\
\hline 62 & $\begin{array}{l}\text { Analyzing temporal changes in urban forest structure and the effect } \\
\text { on air quality improvement }\end{array}$ & $\begin{array}{l}\text { Sustainable Cities } \\
\text { and Society }\end{array}$ & 2019 & 48 & 101548 & & 10.1016/j.scs.2019.101548 \\
\hline 63 & $\begin{array}{c}\text { Under one canopy? Assessing the distributional environmental } \\
\text { justice implications of street tree benefits in Barcelona }\end{array}$ & $\begin{array}{l}\text { Environmental } \\
\text { Science \& Policy }\end{array}$ & 2019 & 102 & $54-64$ & & 10.1016/j.envsci.2019.08.016 \\
\hline 64 & $\begin{array}{l}\text { Dynamics of Urbanization and its impact on Urban Ecosystem } \\
\text { Services (UESs): A study of a medium size town of West Bengal, } \\
\text { Eastern India }\end{array}$ & $\begin{array}{l}\text { Journal of Urban } \\
\text { Management }\end{array}$ & 2019 & 8 & $420-434$ & 3 & 10.1016/j.jum.2019.03.002 \\
\hline 65 & $\begin{array}{l}\text { Urban ecosystem conditions and ecosystem services-a comparison } \\
\text { between large urban zones and city cores in the EU }\end{array}$ & $\begin{array}{l}\text { Journal of } \\
\text { Environmental } \\
\text { Planning and } \\
\text { Management }\end{array}$ & 2019 & 63 & $798-817$ & 5 & $10.1080 / 09640568.2019 .1613966$ \\
\hline 66 & $\begin{array}{l}\text { Multitemporal Geospatial Evaluation of Urban Agriculture and } \\
\text { (Non)-Sustainable Food Self-Provisioning in Milan, Italy }\end{array}$ & Sustainability & 2019 & 11 & 1846 & 7 & $10.3390 /$ su11071846 \\
\hline 67 & $\begin{array}{l}\text { Mapping the social values for ecosystem services in urban green } \\
\text { spaces: Integrating a visitor-employed photography method } \\
\text { into SolVES }\end{array}$ & $\begin{array}{l}\text { Urban Forestry \& } \\
\text { Urban Greening }\end{array}$ & 2019 & 38 & $105-113$ & & 10.1016/j.ufug.2018.11.012 \\
\hline 68 & $\begin{array}{l}\text { Tree Cover for the Year } 2010 \text { of the Metropolitan Region of São } \\
\text { Paulo, Brazil }\end{array}$ & Data & 2019 & 4 & 145 & 4 & $10.3390 /$ data 4040145 \\
\hline 69 & $\begin{array}{l}\text { Identifying urban vegetation stress factors based on open access } \\
\text { remote sensing imagery and field observations }\end{array}$ & $\begin{array}{l}\text { Ecological } \\
\text { Informatics }\end{array}$ & 2020 & 55 & 101,032 & & 10.1016/j.ecoinf.2019.101032 \\
\hline 70 & $\begin{array}{l}\text { Evaluating the contribution of urban ecosystem services in regulating } \\
\text { thermal comfort }\end{array}$ & $\begin{array}{l}\text { Spatial Information } \\
\text { Research }\end{array}$ & 2020 & & 12 & & $10.1007 / \mathrm{s} 41324-020-00336-8$ \\
\hline 71 & $\begin{array}{l}\text { A Multidimensional Assessment Model Using RE-3DSG Sensors on } \\
\text { Net ES and GVR for Sustainable and Smart Cities }\end{array}$ & Sensors (Basel) & 2020 & 20 & 16 & 5 & $10.3390 / \mathrm{s} 20051259$ \\
\hline
\end{tabular}


Table A1. Cont.

\begin{tabular}{|c|c|c|c|c|c|c|c|}
\hline Sr. No. & Title & Journal & Year & Vol & Page(s) & Issue & DOI \\
\hline 72 & $\begin{array}{l}\text { Investigating the Patterns and Dynamics of Urban Green Space in } \\
\text { China's } 70 \text { Major Cities Using Satellite Remote Sensing }\end{array}$ & Remote Sensing & 2020 & 12 & 1929 & 12 & $10.3390 /$ rs12121929 \\
\hline 73 & $\begin{array}{l}\text { Children's green walk to school: An evaluation of welfare-related } \\
\text { disparities in the visibility of greenery among children }\end{array}$ & $\begin{array}{l}\text { Environmental } \\
\text { Science \& Policy }\end{array}$ & 2020 & 110 & $10-13$ & & 10.1016/j.envsci.2020.05.009 \\
\hline 74 & $\begin{array}{l}\text { A multi-criteria spatial approach for mapping urban ecosystem } \\
\text { services demand }\end{array}$ & Ecological Indicators & 2020 & 112 & 106,119 & & 10.1016/j.ecolind.2020.106119 \\
\hline 75 & $\begin{array}{l}\text { Towards nationally harmonized mapping and quantification of } \\
\text { ecosystem services }\end{array}$ & Sci Total Environ & 2020 & 703 & 134,973 & & 10.1016/j.scitotenv.2019.134973 \\
\hline 76 & $\begin{array}{c}\text { Ecosystem services mapping for green infrastructure planning-The } \\
\text { case of Tehran }\end{array}$ & Sci Total Environ & 2020 & 703 & 135,466 & & 10.1016/j.scitotenv.2019.135466 \\
\hline 77 & $\begin{array}{l}\text { Environmental justice and outdoor recreation opportunities: A } \\
\text { spatially explicit assessment in Oslo metropolitan area, Norway }\end{array}$ & $\begin{array}{l}\text { Environmental } \\
\text { Science \& Policy }\end{array}$ & 2020 & 108 & $133-143$ & & 10.1016/j.envsci.2020.03.014 \\
\hline 78 & $\begin{array}{c}\text { Mapping trade-offs and synergies among peri-urban ecosystem } \\
\text { services to address spatial policy }\end{array}$ & $\begin{array}{l}\text { Environmental } \\
\text { Science \& Policy }\end{array}$ & 2020 & 112 & $79-90$ & & 10.1016/j.envsci.2020.06.002 \\
\hline 79 & $\begin{array}{l}\text { Spatiotemporal dynamics of urban ecosystem services in Turkey: The } \\
\text { case of Bornova, Izmir }\end{array}$ & $\begin{array}{l}\text { Urban Forestry \& } \\
\text { Urban Greening }\end{array}$ & 2020 & 49 & 126,631 & & 10.1016/j.ufug.2020.126631 \\
\hline
\end{tabular}




\section{References}

1. Costanza, R. Embodied energy and economic valuation. Science 1980, 210, 1219-1224. [CrossRef] [PubMed]

2. Costanza, R.; d'Arge, R.; De Groot, R.; Farber, S.; Grasso, M.; Hannon, B.; Limburg, K.; Naeem, S.; O'neill, R.V.; Paruelo, J. The value of the world's ecosystem services and natural capital. Nature 1997, 387, 253-260. [CrossRef]

3. De Groot, R.S.; Alkemade, R.; Braat, L.; Hein, L.; Willemen, L. Challenges in integrating the concept of ecosystem services and values in landscape planning, management and decision making. Ecol. Complex. 2010, 7, 260-272. [CrossRef]

4. Atif, S.; Saqib, Z.; Ali, A.; Zaman, M.; Akhtar, N.; Fatima, H.; Atif, M.; Farooqi, S. Identification of key-trends and evaluation of contemporary research regarding urban ecosystem services: A path towards socio-ecological sustainability of urban areas. Appl. Ecol. Environ. Res. 2018, 16, 3545-3581. [CrossRef]

5. Schreyer, J.; Lakes, T. Remote sensing-based approaches for modeling 3D vegetation information in urban areas. In Proceedings of the 2014 14th International Conference on Computational Science and Its Applications, Guimaraes, Portugal, 30 June-3 July 2014; pp. 116-120.

6. Langemeyer, J.; Baró, F.; Roebeling, P.; Gómez-Baggethun, E. Contrasting values of cultural ecosystem services in urban areas: The case of park Montjuïc in Barcelona. Ecosyst. Serv. 2015, 12, 178-186.

7. Ahern, J.; Cilliers, S.; Niemelä, J. The concept of ecosystem services in adaptive urban planning and design: A framework for supporting innovation. Landsc. Urban Plan. 2014, 125, 254-259. [CrossRef]

8. Bokhari, S.A.; Saqib, Z.; Ali, A.; Mahmud, A.; Akhtar, N.; Kanwal, A.; ul Haq, M.Z. The impacts of land use/land cover changes on the supply-demand budget of urban ecosystem services. Arab. J. Geosci. 2021, 14, 1402. [CrossRef]

9. Peptenatu, D.; Pintilii, R.; Draghici, C.; Stoian, D. Environmental pollution in functionally restructured urban areas: Case Study-The City of Bucharest. J. Environ. Health Sci. Eng. 2010, 7, 87-96.

10. Uttara, S.; Bhuvandas, N.; Aggarwal, V. Impacts of urbanization on environment. Int. J. Res. Eng. Appl. Sci. 2012, 2, $1637-1645$.

11. Ahmad, M.; Jiang, P.; Majeed, A.; Umar, M.; Khan, Z.; Muhammad, S. The dynamic impact of natural resources, technological innovations and economic growth on ecological footprint: An advanced panel data estimation. Resour. Policy 2020,69, 101817. [CrossRef]

12. Nath, P.K.; Behera, B. A critical review of impact of and adaptation to climate change in developed and developing economies Environ. Dev. Sustain. 2011, 13, 141-162. [CrossRef]

13. Akhtar, N.; Saqib, Z.; Khan, M.I.; Martin, M.A.; Atif, S.B.; Zaman, M.H. A bibliometric analysis of contemporary research regarding industrial symbiosis: A path towards urban environmental resilience. Appl. Ecol. Environ. Res. 2018, 17, 1159-1221. [CrossRef]

14. Atif, S.; Saqib, Z.; Ali, A.; Zaman, M. The impacts of socio-economic factors on the perception of residents about urban vegetation: A comparative study of planned versus semi-planned cities of Islamabad and Rawalpindi, Pakistan. Appl. Ecol. Environ. Res. 2018, 16, 4265-4287. [CrossRef]

15. Amir, S.; Saqib, Z.; Khan, M.I.; Khan, M.A.; Bokhari, S.A.; Zaman-ul-Haq, M.; Majid, A. Farmers' perceptions and adaptation practices to climate change in rain-fed area: A case study from district Chakwal, Pakistan. Pak. J. Agric. Sci. 2020, 57, 465-475.

16. Zaman, H.M.; Saqib, Z.; Atif, B.S.; Akhtar, N.; Amir, S. The Dynamics of Urbanizations and Concomitant Land Use Land Cover Transformations in Planned and Quasi-Planned Urban Settlements of Pakistan. Geogr. Environ. Sustain. 2020, 13, 4. [CrossRef]

17. Alavipanah, S.; Haase, D.; Lakes, T.; Qureshi, S. Integrating the third dimension into the concept of urban ecosystem services: A review. Ecol. Indic. 2017, 72, 374-398. [CrossRef]

18. Thapa, R.B. Monitoring landscape change in Kathmandu metropolitan region using multi-temporal satellite imagery. In Proceedings of the Earth Observing Missions and Sensors: Development, Implementation, and Characterization II, Tokyo, Japan, 30 October-1 November 2012; p. 85281P.

19. Luederitz, C.; Brink, E.; Gralla, F.; Hermelingmeier, V.; Meyer, M.; Niven, L.; Panzer, L.; Partelow, S.; Rau, A.-L.; Sasaki, R. A review of urban ecosystem services: Six key challenges for future research. Ecosyst. Serv. 2015, 14, 98-112. [CrossRef]

20. Paul, C.K.; Mascarenhas, A.C. Remote sensing in development. Science 1981, 214, 139-145. [CrossRef]

21. Pettorelli, N.; Laurance, W.F.; O’Brien, T.G.; Wegmann, M.; Nagendra, H.; Turner, W. Satellite remote sensing for applied ecologists: Opportunities and challenges. J. Appl. Ecol. 2014, 51, 839-848. [CrossRef]

22. Kwok, R. Ecology's remote-sensing revolution. Nature 2018, 556, 137-138. [CrossRef]

23. Kremer, P.; Hamstead, Z.A.; McPhearson, T. The value of urban ecosystem services in New York City: A spatially explicit multicriteria analysis of landscape scale valuation scenarios. Environ. Sci. Policy 2016, 62, 57-68. [CrossRef]

24. Wang, J.; Zhou, W.; Qian, Y.; Li, W.; Han, L. Quantifying and characterizing the dynamics of urban greenspace at the patch level: A new approach using object-based image analysis. Remote Sens. Environ. 2018, 204, 94-108. [CrossRef]

25. Wang, Y.; Li, X.; Zhang, Q.; Li, J.; Zhou, X. Projections of future land use changes: Multiple scenarios-based impacts analysis on ecosystem services for Wuhan city, China. Ecol. Indic. 2018, 94, 430-445. [CrossRef]

26. Greene, C.S.; Millward, A.A. Getting closure: The role of urban forest canopy density in moderating summer surface temperatures in a large city. Urban Ecosyst. 2017, 20, 141-156. [CrossRef]

27. Estoque, R.C.; Murayama, Y.; Myint, S.W. Effects of landscape composition and pattern on land surface temperature: An urban heat island study in the megacities of Southeast Asia. Sci. Total Environ. 2017, 577, 349-359. [CrossRef]

28. Chang, J.; Qu, Z.; Xu, R.; Pan, K.; Xu, B.; Min, Y.; Ren, Y.; Yang, G.; Ge, Y. Assessing the ecosystem services provided by urban green spaces along urban center-edge gradients. Sci. Rep. 2017, 7, 11226. [CrossRef] 
29. Zhao, C.; Sander, H.A. Assessing the sensitivity of urban ecosystem service maps to input spatial data resolution and method choice. Landsc. Urban Plan. 2018, 175, 11-22. [CrossRef]

30. Tyukavina, A.; Hansen, M.C.; Potapov, P.V.; Stehman, S.V.; Smith-Rodriguez, K.; Okpa, C.; Aguilar, R. Types and rates of forest disturbance in Brazilian Legal Amazon, 2000-2013. Sci. Adv. 2017, 3, e1601047. [CrossRef]

31. Wang, X.; Zhang, F.; Ding, J. Evaluation of water quality based on a machine learning algorithm and water quality index for the Ebinur Lake Watershed, China. Sci. Rep. 2017, 7, 12858. [CrossRef]

32. Vafaei, S.; Soosani, J.; Adeli, K.; Fadaei, H.; Naghavi, H.; Pham, T.D.; Bui, D.T. Improving accuracy estimation of Forest Aboveground Biomass based on incorporation of ALOS-2 PALSAR-2 and Sentinel-2A imagery and machine learning: A case study of the Hyrcanian forest area (Iran). Remote Sens. 2018, 10, 172. [CrossRef]

33. Elmqvist, T.; Setälä, H.; Handel, S.; Van Der Ploeg, S.; Aronson, J.; Blignaut, J.N.; Gomez-Baggethun, E.; Nowak, D.; Kronenberg, J.; De Groot, R. Benefits of restoring ecosystem services in urban areas. Curr. Opin. Environ. Sustain. 2015, 14, 101-108. [CrossRef]

34. Bibri, S.E.; Krogstie, J. Smart sustainable cities of the future: An extensive interdisciplinary literature review. Sustain. Cities Soc. 2017, 31, 183-212. [CrossRef]

35. Nobre, G.C.; Tavares, E. Scientific literature analysis on big data and internet of things applications on circular economy: A bibliometric study. Scientometrics 2017, 111, 463-492. [CrossRef]

36. Türkeli, S.; Kemp, R.; Huang, B.; Bleischwitz, R.; McDowall, W. Circular economy scientific knowledge in the European Union and China: A bibliometric, network and survey analysis (2006-2016). J. Clean. Prod. 2018, 197, 1244-1261. [CrossRef]

37. Goyal, S.; Chauhan, S.; Mishra, P. Circular economy research: A bibliometric analysis (2000-2019) and future research insights. J. Clean. Prod. 2021, 287, 125011. [CrossRef]

38. Booth, A.; Sutton, A.; Papaioannou, D. Systematic Approaches to a Successful Literature Review, 2nd ed.; SAGE Publications: Thousand Oaks, CA, USA, 2016.

39. McDonnell, M.J.; MacGregor-Fors, I. The ecological future of cities. Science 2016, 352, 936-938. [CrossRef]

40. $\mathrm{Wu}, \mathrm{J}$. Urban ecology and sustainability: The state-of-the-science and future directions. Landsc. Urban Plan. 2014, 125, $209-221$. [CrossRef]

41. Schetke, S.; Qureshi, S.; Lautenbach, S.; Kabisch, N. What determines the use of urban green spaces in highly urbanized areas?-Examples from two fast growing Asian cities. Urban For. Urban Green. 2016, 16, 150-159. [CrossRef]

42. Świąder, M.; Szewrański, S.; Kazak, J.K.; Van Hoof, J.; Lin, D.; Wackernagel, M.; Alves, A. Application of ecological footprint accounting as a part of an integrated assessment of environmental carrying capacity: A case study of the footprint of food of a large city. Resources 2018, 7, 52. [CrossRef]

43. de Araujo Barbosa, C.C.; Atkinson, P.M.; Dearing, J.A. Remote sensing of ecosystem services: A systematic review. Ecol. Indic. 2015, 52, 430-443. [CrossRef]

44. Masnavi, M.R.; Dabiri, M. The Potential of Urban Ecosystem Services Valuation as a Tool for Planning More Sustainable Cities. MANZAR Sci. J. Landsc. 2018, 9, 24-35.

45. Haase, D.; Frantzeskaki, N.; Elmqvist, T. Ecosystem services in urban landscapes: Practical applications and governance implications. Ambio 2014, 43, 407-412. [CrossRef] [PubMed]

46. Fink, H.S. Human-nature for climate action: Nature-based solutions for urban sustainability. Sustainability 2016, 8, 254. [CrossRef]

47. Neefjes, K. Environments and Livelihoods: Strategies for Sustainability; Oxfam: Boston, MA, USA, 2000.

48. Larondelle, N.; Haase, D.; Kabisch, N. Mapping the diversity of regulating ecosystem services in European cities. Glob. Environ. Chang. 2014, 26, 119-129. [CrossRef]

49. Tavares, P.A.; Beltrão, N.; Guimarães, U.S.; Teodoro, A.; Gonçalves, P. Urban ecosystem services quantification through remote sensing approach: A systematic review. Environments 2019, 6, 51. [CrossRef]

50. Poursanidis, D.; Chrysoulakis, N. Remote Sensing, natural hazards and the contribution of ESA Sentinels missions. Remote Sens. Appl. Soc. Environ. 2017, 6, 25-38. [CrossRef]

51. Li, J.; Roy, D.P. A global analysis of Sentinel-2A, Sentinel-2B and Landsat-8 data revisit intervals and implications for terrestrial monitoring. Remote Sens. 2017, 9, 902. [CrossRef]

52. Huang, S.-L.; Chen, Y.-H.; Kuo, F.-Y.; Wang, S.-H. Emergy-based evaluation of peri-urban ecosystem services. Ecol. Complex. 2011, 8, 38-50. [CrossRef]

53. Calderón-Contreras, R.; Quiroz-Rosas, L.E. Analysing scale, quality and diversity of green infrastructure and the provision of Urban Ecosystem Services: A case from Mexico City. Ecosyst. Serv. 2017, 23, 127-137. [CrossRef]

54. Sylla, M.; Hagemann, N.; Szewrański, S. Mapping trade-offs and synergies among peri-urban ecosystem services to address spatial policy. Environ. Sci. Policy 2020, 112, 79-90. [CrossRef]

55. Ramyar, R.; Saeedi, S.; Bryant, M.; Davatgar, A.; Hedjri, G.M. Ecosystem services mapping for green infrastructure planning-The case of Tehran. Sci. Total Environ. 2020, 703, 135466. [CrossRef] [PubMed]

56. Li, F.; Guo, S.; Li, D.; Li, X.; Li, J.; Xie, S. A multi-criteria spatial approach for mapping urban ecosystem services demand. Ecol. Indic. 2020, 112, 106119. [CrossRef]

57. Coskun-Hepcan, C.; Hepcan, S. Assessing ecosystem services of Bornova's green infrastructure, Izmir (Turkey). Fresenius Environ. Bull. 2018, 27, 3530-3541.

58. Jia, J.; Wu, X. A Multidimensional Assessment Model Using RE-3DSG Sensors on Net ES and GVR for Sustainable and Smart Cities. Sensors 2020, 20, 1259. [CrossRef] [PubMed] 
59. Tigges, J.; Lakes, T.; Hostert, P. Urban vegetation classification: Benefits of multitemporal RapidEye satellite data. Remote Sens. Environ. 2013, 136, 66-75. [CrossRef]

60. Haas, J.; Ban, Y. Mapping and monitoring urban ecosystem services using multitemporal high-resolution satellite data. IEEE J. Sel. Top. Appl. Earth Obs. Remote Sens. 2016, 10, 669-680. [CrossRef]

61. Lakes, T.; Kim, H.-O. The urban environmental indicator "Biotope Area Ratio"-An enhanced approach to assess and manage the urban ecosystem services using high resolution remote-sensing. Ecol. Indic. 2012, 13, 93-103. [CrossRef]

62. Li, W.; Saphores, J.-D.M.; Gillespie, T.W. A comparison of the economic benefits of urban green spaces estimated with NDVI and with high-resolution land cover data. Landsc. Urban Plan. 2015, 133, 105-117. [CrossRef]

63. Van de Voorde, T. Spatially explicit urban green indicators for characterizing vegetation cover and public green space proximity: A case study on Brussels, Belgium. Int. J. Digit. Earth 2017, 10, 798-813. [CrossRef]

64. Kuittinen, M.; Moinel, C.; Adalgeirsdottir, K. Carbon sequestration through urban ecosystem services: A case study from Finland Sci. Total Environ. 2016, 563, 623-632. [CrossRef]

65. Larondelle, N.; Lauf, S. Balancing demand and supply of multiple urban ecosystem services on different spatial scales. Ecosyst. Serv. 2016, 22, 18-31. [CrossRef]

66. Zinia, N.J.; McShane, P. Significance of urban green and blue spaces: Identifying and valuing provisioning ecosystem services in Dhaka City. Eur. J. Sustain. Dev. 2018, 7, 435. [CrossRef]

67. Das, M.; Das, A. Dynamics of Urbanization and its impact on Urban Ecosystem Services (UESs): A study of a medium size town of West Bengal, Eastern India. J. Urban Manag. 2019, 8, 420-434. [CrossRef]

68. Sha, Z.; Ali, Y.; Wang, Y.; Chen, J.; Tan, X.; Li, R. Mapping the changes in urban greenness based on localized spatial association analysis under temporal context using MODIS data. ISPRS Int. J. Geo-Inf. 2018, 7, 407. [CrossRef]

69. Chen, Y.; Fan, R.; Yang, X.; Wang, J.; Latif, A. Extraction of urban water bodies from high-resolution remote-sensing imagery using deep learning. Water 2018, 10, 585. [CrossRef]

70. Li, Y.; Xue, C.; Shao, H.; Shi, G.; Jiang, N. Study of the spatiotemporal variation characteristics of forest landscape patterns in Shanghai from 2004 to 2014 based on multisource remote sensing data. Sustainability 2018, 10, 4397. [CrossRef]

71. Burkhard, B.; Kroll, F.; Nedkov, S.; Müller, F. Mapping ecosystem service supply, demand and budgets. Ecol. Indic. 2012, 21, 17-29. [CrossRef]

72. Tavares, P.A.; Beltrão, N.E.S.; Guimarães, U.S.; Teodoro, A.C. Integration of sentinel-1 and sentinel-2 for classification and LULC mapping in the urban area of Belém, eastern Brazilian Amazon. Sensors 2019, 19, 1140. [CrossRef]

73. Whyte, A.; Ferentinos, K.P.; Petropoulos, G.P. A new synergistic approach for monitoring wetlands using Sentinels-1 and 2 data with object-based machine learning algorithms. Environ. Model. Softw. 2018, 104, 40-54. [CrossRef] 